\title{
The effect of diet on microfaunal population and function in the caecum of a subterranean naked mole-rat, Heterocephalus glaber
}

\author{
BY ROCHELLE BUFFENSTEIN AND SHLOMO YAHAV \\ Physiology Department, University of the Witwatersrand, Medical School, 7 York Road, Parktown, \\ Johannesburg 2193, South Africa
}

(Received 19 January 1990-Accepted 6 September 1990)

\begin{abstract}
The effect of dietary fibre and starch content on digestibility, microfaunal population and caecal function was investigated in a subterranean mole-rat, Heterocephalus glaber (Rodentia). Mole-rats were fed on a diet of either sweet potato (neutral-detergent fibre (NDF) $65 \mathrm{~g} / \mathrm{kg}$ dry matter (DM), starch $638 \mathrm{~g} / \mathrm{kg}$ DM) or earrot (NDF $157 \mathrm{~g} / \mathrm{kg}$ DM, starch $258.7 \mathrm{~g} / \mathrm{kg}$ DM) for 4 weeks. Daily intake and faecal output were monitored. Thereafter caecal microfaunal population, density and function were assessed using light and scanning electron microscopy and by measuring both gas and short chain fatty acid (SCFA) production. A 2.4-fold increase in fibre and 2-5-fold decrease in starch content resulted in a decrease in caecal DM content $(390 \mathrm{~g} / \mathrm{kg})$. A concomitant dramatic decline (by $93 \%$ ) in ciliate protozoa with a corresponding 2-fold increase in bacteria also accompanied this change in diet. Fermentative efficiency as indicated by gas production was 2.6 times greater on a carrot diet than on sweet potato. Microbial fermentation resulted in higher SCFA concentrations on the carrot diet, with a $42 \%$ reduction in SCFA concentration on the sweet potato diet. Here, SCFA contributed $5.1 \%$ of daily energy expenditure and this increased 5.0-fold on the carrot diet. Caecal micro-organism function, therefore, played an important role in the nutritional physiology of these naked mole-rats, and enabled maximum utilization of the food substrate.
\end{abstract}

Caecal fermentation: Dietary fibre: Mole-rat

Most of the energy produced by plants is stored in the structural polymers comprising the plant cell walls and plant fibre, yet vertebrates, generally, do not possess the necessary digestive enzymes to tap this energy source. Energy from these plant polysaccharides only becomes available to mammals via micro-organism-controlled fermentation processes which occur primarily in specialized regions of the gut, namely the rumen or caecum. These fermentation chambers contribute significantly to the body mass of the animal, providing a capacious vat in which plant material may be degraded (McBee, 1977; Parra, 1978). In addition non-digested $\alpha$-amylase ( $E C$ 3.2.1.1)-resistant starch may also accumulate in these fermentation vats and supplement the substrate utilized by microbial organisms (Cummings \& Englyst, 1987).

In rodents, fermentation occurs primarily in the caecal region of the hind-gut (McBee, 1977). The major end-products of this anaerobic process are short chain fatty acids (SCFA; such as acetic, propionic and butyric acids) and gaseous waste products, i.e. carbon dioxide, hydrogen and methane. The SCFA are absorbed during passage through the large intestine and are used as a source of energy by the animal. The actual energy contribution of the SCFA however, may vary with food quality and diet (Rechkemmer et al. 1988).

The rate of SCFA production alters in response to changes in food quality (McBee, 1970). Other changes in response to a deterioration in food quality include an increase in food intake (Janis, 1976) and an increase in caecal volume (Sibly, 1981; Gross et al. 1985; Yahav \& Choshniak, 1991). Change in caecal volume is attributed to several factors, ie. (1) 
Table 1. Nutritional information of the foods used in the study

\begin{tabular}{lcc} 
& & \\
& Sweet potato & Carrots \\
& & \\
Dry matter (g/kg wet wt) & 163.2 & 79.0 \\
Energy (kJ/g DM) & 15.8 & 18.5 \\
NDF (g/kg DM) & 64.7 & 156.6 \\
Starch (g/kg DM) & 638.8 & 257.6 \\
\hline
\end{tabular}

DM, dry matter; NDF, neutral-detergent fibre.

change in food intake and the concomitant change in bulk of contents (Wyatt et al. 1988), (2) an accumulation of non-digestible polysaccharides (Wyatt et al. 1988), (3) changes in SCFA concentration (Sakata, 1987), (4) changes in the microbial population (El Harith et al. 1976).

Despite the plethora of studies on herbivorous nutrition, little is known about digestive modifications increasing nutrient assimilation on poor quality food. It is also not known whether subterranean mammals living on underground plant material employ similar ways of maximizing food usage. In the present investigation, the influence of dietary fibre content on caecal volume and function was investigated in a subterranean arid zone inhabitant, i.e. the naked mole-rat Heterocephalus glaber (Rodentia; Bathyergidae).

The distribution of this mammal is restricted to the semi-arid and arid zones of equatorial North East Africa (Kingdom, 1974). Here, these naked mole-rats lead a strictly subterranean existence (chthonic) in an extensive maze of underground burrows (Jarvis \& Bennett, 1990). These burrows are continually extended in search of food. There is, therefore, a high cost associated with the location of the randomly distributed food supplies (Lovegrove, 1989) and it would be most advantageous to utilize this food efficiently. The roots and tubers constituting the mole-rats' diet are, invariably, relatively high in fibre. In addition, the hind-gut of these mole-rats is proportionately large and is teeming with large numbers of protozoa (Porter, 1957; Plate 1). It is, therefore, speculated that fermentation of fibre might be of nutritional importance to these animals.

We therefore examined the importance of micro-organisms in gut function and the effect of diet on microfaunal population, density and activity. Caecal function and efficacy improved when the animals were fed on a diet with a high fibre content and low starch content. This was attributed to marked changes in both caecal size and microfaunal populations.

\section{MATERIALS AND METHODS}

Nineteen mature (25-49 g) naked mole-rats born in captivity were used in the study. These animals were fed on a diet of either sweet potato (SP) or carrot (CAR). The nutritional information of these foods is given in Table 1.

\section{Animal maintenance}

Animals were housed individually in metabolic cages in a climatically controlled room. Air temperature was $30 \pm 1^{\circ}$ and relative humidity was $70-80 \%$. All nineteen individuals were fed $a d$ lib. on a diet of SP. Thereafter the diet of nine of these animals was changed to carrot (CAR).

\section{Experimental procedures}

Naked mole-rats were maintained on each diet for 4 weeks. Body mass, food intake and faecal output were monitored daily for the last $14 \mathrm{~d}$ of each treatment. Food samples and faeces were collected and dried to constant mass at $70^{\circ}$. Energy values of all samples were 
then determined by bomb calorimetry (Digital Data Systems). Thereafter all animals were killed by injecting Euthenase (Centaur Labs, Johannesburg) intraperitoneally (200 mg sodium pentabarbitone $/ \mathrm{ml}: 0.01 \mathrm{ml} / \mathrm{g}$ body-weight). The gastrointestinal tract was immediately removed intact, and the caecum separated from the rest of the gut. This was weighed, and then mixed to obtain uniform portions of caecal contents. Weighed portions (approximately $0.3 \mathrm{~g}$ ) were taken and immediately used in the fermentation studies and in the determination of percentage dry matter (DM).

\section{Fermentation capacity}

The rates of gas production and SCFA production were measured to determine fermentation capacity. This was done by transferring the weighed caecal sample to a $25 \mathrm{ml}$ Warburg flask and displacing the air within the flask with $\mathrm{CO}_{2}$. The manometric apparatus was kept open allowing the displacement of $\mathrm{CO}_{2}$ by the gases produced during fermentation. Thereafter, the flasks were sealed and incubated at $33^{\circ}$, the optimal temperature for caecal function in these animals (Yahav \& Buffenstein, 1991). The volume of gas produced in the flasks was monitored every $5 \mathrm{~min}$ for $1 \mathrm{~h}$ using standard manometric techniques. After each measurement the manometric system was opened to release the gas produced. The rate of gas production at the time the caecum was incised was extrapolated from the exponential relationship between gas production and time, in compliance with the methods of Carol \& Hungate (1954). On completion of gas production measurements, a gas sample was taken directly from the fermentation flask using evacuated tubes. The concentrations of $\mathrm{CO}_{2}$, $\mathrm{CH}_{4}$ and $\mathrm{H}_{2}$ in the gas samples were determined by gas-liquid chromatography (Perkin Elmer 881).

The rate of SCFA production was determined from the SCFA concentration in caecal samples taken after excising the caecum and those taken after the completion of gas production measurements (McBee, 1970). Known amounts of sodium hydroxide (100 g/l) were added to each sample. These samples were then stored at $-20^{\circ}$ for later analysis. The concentration of SCFA was determined using gas-liquid chromatography (Carlo Erba Strumentzione 4200) using pivalic acid as an internal standard.

The DM content was determined by taking weighed portions of caecal contents and drying these at $70^{\circ}$ to constant mass.

\section{Micro-organism analysis}

Bacteria and protozoa present in the caecal fluid were counted directly using a haemacytometer (1/10 deep) and light microscopy. Portions of caecal fluid were also fixed with glutaraldehyde $(100 \mathrm{~g} / \mathrm{l})$ and used in scanning electron microscopy. Microbial organisms present in the caecal fluid were thus photographed.

\section{Statistical analyses}

All results are expressed as means with their standard errors. A Kolmogorov-Smirnov goodness of fit test was carried out on the raw data and confirmed that the data fitted a normal distribution. Thereafter the unpaired Student's $t$ test (two-tailed) was used to test for significance between the two diets. Results were considered significantly different at $P<0.05$. Zar (1984) was consulted for the determination of the appropriate statistics.

\section{RESULTS}

Over the experimental period, irrespective of diet, body mass did not change by more than $2 \%$ of the initial body mass (Table 2 ). Digestible DM intake and digestibility on CAR was significantly lower $\left(P=1.3 \times 10^{-2}\right.$ and $P=8.0 \times 10^{-3}$ respectively) than that on SP (Table $2)$; however, daily digestible energy intake was similar $(P=0.15)$ on the two diets. Caecal 
Table 2. Effect of change in diet from sweet potato to carrot on body mass, daily intake of digestible DM and energy in naked mole-rats (Heterocephalus glaber)

(Mean values with their standard errors)

\begin{tabular}{|c|c|c|c|c|c|c|}
\hline \multirow[t]{2}{*}{ No. of animals... } & \multicolumn{2}{|c|}{$\begin{array}{c}\text { Sweet potato } \\
19\end{array}$} & \multicolumn{2}{|c|}{$\begin{array}{c}\text { Carrots } \\
9\end{array}$} & \multirow{2}{*}{$\begin{array}{l}\text { Confidence interval }(\mathrm{Cl}) \\
\text { for differences }\end{array}$} & \multirow{2}{*}{$\begin{array}{c}\text { Statistical } \\
\text { significance } \\
\text { of } \\
\text { difference: } \\
P\end{array}$} \\
\hline & Mean & SE & Mean & SE & & \\
\hline Body mass $(\mathrm{g})$ & $41 \cdot 5$ & $1 \cdot 9$ & $32 \cdot 4$ & $2 \cdot 33$ & & \\
\hline $\begin{array}{l}\text { Change in body mass } \\
\text { over period of } \\
\text { monitoring }(\%)\end{array}$ & 1.01 & 0.43 & $--0 \cdot 22$ & $0 \cdot 35$ & $-1.23(95 \%$ CI $-2.66,0.20)$ & $9 \cdot 0 \times 10^{-2}$ \\
\hline $\begin{array}{l}\text { Digestible DM intake } \\
(\mathrm{g} / \mathrm{kg} \text { body mass } \\
\text { per } \mathrm{d})\end{array}$ & $20 \cdot 9$ & $1 \cdot 44$ & $14 \cdot 9$ & $1 \cdot 46$ & $-5 \cdot 83(95 \% \mathrm{CI}-10 \cdot 34,-1.32)$ & $1.3 \times 10^{-2}$ \\
\hline $\begin{array}{l}\text { Digestible energy intake } \\
\left(\mathrm{kJ} / \mathrm{kg} \text { body mass }{ }^{0.75}\right. \\
\text { per d) }\end{array}$ & $330 \cdot 61$ & 21.08 & $275 \cdot 55$ & $25 \cdot 42$ & $52 \cdot 82(95 \% \mathrm{CI}--21 \cdot 24,126.86)$ & $1.5 \times 10^{-1}$ \\
\hline $\begin{array}{l}\text { Faecal output } \\
(\mathrm{kJ} / \mathrm{kg} \text { body mass } \\
\text { per d })\end{array}$ & $17 \cdot 81$ & $2 \cdot 15$ & $29 \cdot 31$ & 3.08 & $-11.51(95 \%$ CI $-19.50,-3.43)$ & $7 \cdot 0 \times 10^{-3}$ \\
\hline Digestibility of DM $(\%)$ & $94 \cdot 6$ & $0 \cdot 92$ & $89 \cdot 4$ & 1.73 & $5 \cdot 11(95 \% \mathrm{Cl} 1.47,8 \cdot 76)$ & $8.0 \times 10^{-3}$ \\
\hline $\begin{array}{l}\text { Digestibility of dietary } \\
\text { energy }(\%)\end{array}$ & $94 \cdot 2$ & $0 \cdot 82$ & $88 \cdot 8$ & $1 \cdot 20$ & $5.40(95 \%$ CI $2 \cdot 29,8 \cdot 51)$ & $1.0 \times 10^{-3}$ \\
\hline
\end{tabular}

DM, dry matter.

Table 3. The effect of diet* on caecal mass, caecal content and micro-organism population in naked mole-rats (Heterocephalus glaber)

(Mean values with their standard errors)

\begin{tabular}{|c|c|c|c|c|c|c|}
\hline \multirow[t]{2}{*}{ No. of animals... } & \multicolumn{2}{|c|}{$\begin{array}{c}\text { Sweet potato } \\
10\end{array}$} & \multicolumn{2}{|c|}{$\begin{array}{l}\text { Carrots } \\
8\end{array}$} & \multirow{2}{*}{$\begin{array}{l}\text { Confidence interval (CI) } \\
\text { for differences }\end{array}$} & \multirow{2}{*}{$\begin{array}{c}\text { Statistical } \\
\text { significance } \\
\text { of } \\
\text { difference: } \\
P\end{array}$} \\
\hline & Mean & $\mathrm{SE}$ & Mean & SE & & \\
\hline No. of bacteria $\times 10^{9}(/ \mathrm{ml})$ & 3.63 & 0.84 & $7 \cdot 11$ & $0 \cdot 36$ & $3.23(95 \%$ CI $0.251,6.20)$ & $3.9 \times 10^{-2}$ \\
\hline $\begin{array}{l}\text { No. of protozoa } \times 10^{8} \\
(/ \mathrm{ml})\end{array}$ & $4 \cdot 11$ & 0.88 & 0.07 & $0 \cdot 013$ & $-3.63(95 \% \mathrm{Cl}-6.61,0.647)$ & $2.6 \times 10^{-2}$ \\
\hline Caecal wet wt $(\mathrm{g})$ & $3 \cdot 32$ & 1.05 & 1.95 & 0.13 & $1.18(95 \% \mathrm{Cl} 0.66,1.70)$ & $2 \cdot 1 \times 10^{-4}$ \\
\hline $\begin{array}{l}\text { Caecal contribution to } \\
\text { body mass }(\mathrm{g} / \mathrm{kg})\end{array}$ & $83 \cdot 0$ & $7 \cdot 0$ & $71 \cdot 0$ & $9 \cdot 9$ & $1.57(95 \%$ CI $0.63,3.76)$ & $1.5 \times 10^{-1}$ \\
\hline Caecal dry wt (g) & 0.69 & 0.08 & 0.24 & 0.032 & $0.50(95 \% \mathrm{Cl} 0.23,0.66)$ & $4.2 \times 10^{-4}$ \\
\hline $\begin{array}{l}\text { Caecal dry matter } \\
\text { content }(\mathrm{g} / \mathrm{kg})\end{array}$ & 277.0 & 14.9 & 192.0 & $17 \cdot 3$ & $5.96(95 \% \mathrm{CI}-0.92,12.84)$ & $8.5 \times 10^{-2}$ \\
\hline
\end{tabular}

* For details see Table 1 and p. 250.

mass was concomitantly lower on the CAR diet (Table 3) with a corresponding decrease in DM mass to $35 \%$ of that on SP $\left(P=4.2 \times 10^{-4}\right.$; Table 3$)$.

\section{Microbial population and density}

There was a significant change in micro-organism population and density on the two diets (Table 3). These light microscope findings were supported by scanning electron microscopy 


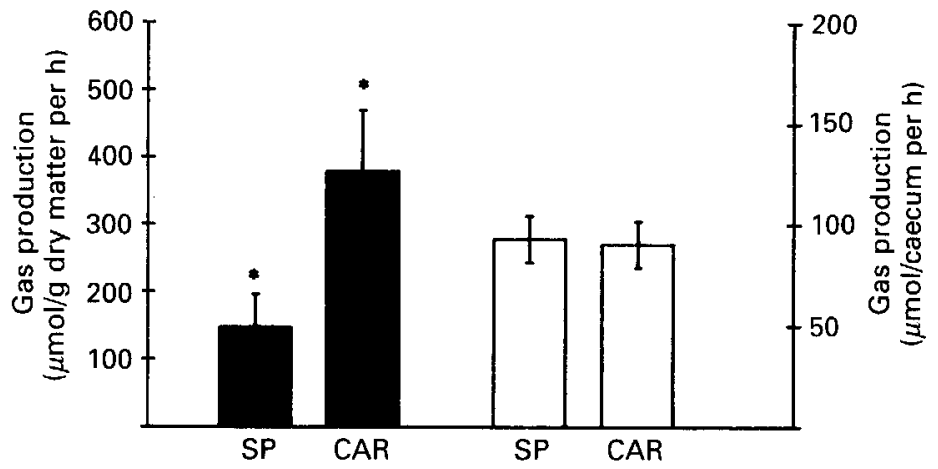

Fig. 1. Rates of gas production during caecal fermentation in the naked mole-rat (Heterocephalus glaber) when fed on a diet of either sweet potato (SP) or carrot (CAR) (for details, see Table 1 and p. 250). Values are means with their standard errors represented by vertical bars, ${ }^{*} P<0 \cdot 01$.

Table 4. The effect of diet ${ }^{*}$ on the proportion of gases produced during fermentation in naked mole-rats (Heterocephalus glaber)

(Mean values with their standard errors)

\begin{tabular}{|c|c|c|c|c|c|c|}
\hline \multirow{3}{*}{ No. of animals... } & \multicolumn{4}{|c|}{ Gas $(\%)$} & \multirow{3}{*}{$\begin{array}{l}\text { Confidence interval (CI) } \\
\text { for differences }\end{array}$} & \multirow{3}{*}{$\begin{array}{c}\text { Statistical } \\
\text { significance } \\
\text { of } \\
\text { difference: } \\
P\end{array}$} \\
\hline & \multicolumn{2}{|c|}{$\begin{array}{c}\text { Sweet potato } \\
10\end{array}$} & \multicolumn{2}{|c|}{$\begin{array}{c}\text { Carrots } \\
9\end{array}$} & & \\
\hline & Mean & $\mathrm{SE}$ & Mean & $\mathrm{SE}$ & & \\
\hline Carbon dioxide & $45 \cdot 2$ & 6.29 & $91 \cdot 2$ & $0 \cdot 11$ & $46.01(95 \% \mathrm{CI}-65.89,-26.13)$ & $6.9 \times 10^{-4}$ \\
\hline Methane & $37 \cdot 6$ & $5 \cdot 76$ & $5 \cdot 2$ & $1 \cdot 20$ & $32.41(95 \%$ CI $40 \cdot 74,50.07)$ & $2.9 \times 10^{-3}$ \\
\hline Hydrogen & $17 \cdot 1$ & 0.78 & $3 \cdot 6$ & 0.64 & $13.58(95 \%$ CI $10 \cdot 30,16 \cdot 86)$ & $1.2 \times 10^{-5}$ \\
\hline
\end{tabular}

* For details, see Table 1 and p. 250.

(Plate $1(a-c)$ ) which showed an abundance of holotrich ciliate protozoa (Plate $1(b, c)$ ) on the SP diet and a conspicuous absence of these ciliates on the CAR diet. The microfaunal population when mole-rats were fed on CAR consisted of fewer and smaller flagellate protozoa (Plate $1(d))$ and proportionately more $\left(P=3.9 \times 10^{-2}\right)$ bacteria (Table 3 and Plate $1(e))$.

\section{Gas production}

Gas production per caecum was similar on both diets (Fig. 1). However, when gas production is expressed per $g$ caecal DM content, it was 2.6 times higher $\left(P=8.3 \times 10^{-9}\right)$ in animals on the CAR diet than in those fed on SP (Fig. 1). The proportions of the three gases produced during fermentation also differed significantly between diets (Table 4). On the CAR diet, almost all the gas produced was $\mathrm{CO}_{2}(912$ (SE 0.11$\left.) \%\right)$. The proportion of $\mathrm{CO}_{2}$ in the total gas production halved $(45.2$ ( $\mathrm{SE} 6.29) \%$ ) when the diet was SP, with methane contributing 37.6 (SE 5.76) \% and hydrogen $17 \cdot 1$ (SE 0.78 ) $\%$ of the gases produced.

\section{$S C F A$}

The main SCFA present in the caecal fluid, on both diets, were acetic, propionic and $n$-butyric acids. The total concentration of these three acids was significantly higher $\left(P=2.7 \times 10^{-4}\right)$ on the CAR diet (Fig. 2). This was attributed to markedly higher 


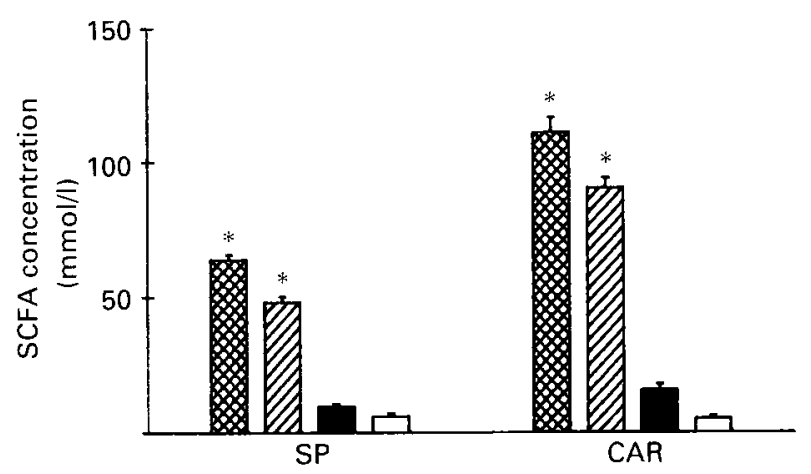

Fig. 2. Concentrations of short chain fatty acids (SCFA) in caecal contents of the naked mole-rat (Heterocephalus glaber) when fed on a diet of either sweet potato (SP) or carrot (CAR) (for details see Table 1 and p. 250). BO, Total SCFA; $\square$, acetic acid; $\square$, propionic acid; $\square$, n-butyric acid. Values are means with their standard errors represented by vertical bars, ${ }^{*} P<0.01$.

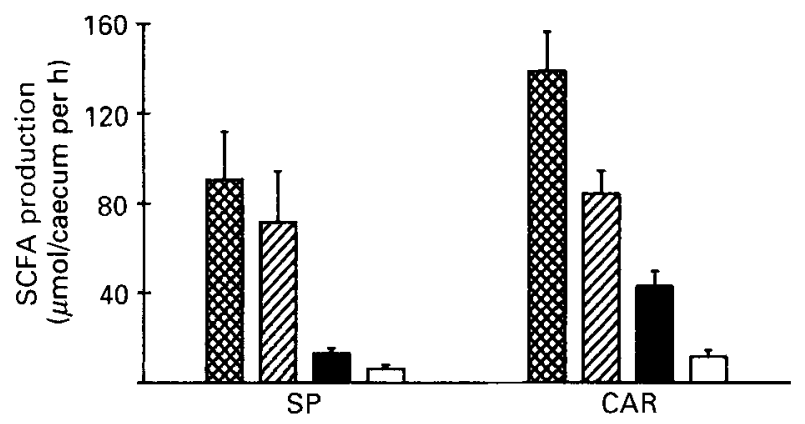

Fig. 3. Rates of caecal short chain fatty acids (SCFA) production in the naked mole-rat (Heterocephalus glaber) when fed on a diet of either sweet potato (SP) or carrot (CAR) (for details, see Table I and p. 250). B. Total SCFA; $\square$, acetic acid; $\square$, propionic acid; $\square, n$-butyric acid. Values are means with their standard errors represented by vertical bars.

concentrations of acetic acid. The rate of SCFA production on the CAR diet was 138.7 (SE 14.0) $\mu \mathrm{mol} /$ caecum per $\mathrm{h}$, and was not significantly different to that $(90.75$ (SE 24.5) $\mu \mathrm{mol} /$ caecum per $\mathrm{h}$ ) found in animals fed on SP (Fig. 3).

\section{DISCUSSION}

Caecal digestion and fermentation appears to play an important nutritional role in naked mole-rats. When the fibre content was low and starch content high (SP), digestibility and food intake were higher than those on a CAR diet with a higher fibre content and lower starch content (Table 2).

Most hind-gut fermentors respond to an increase in dietary fibre by increasing food intake and caecal volume (McBee, 1970; Hoover \& Heitmann, 1972; Janis, 1976; Gross et al. 1985), with a concomitant decline in digestibility (Sibly, 1981; Van Soest, 1982). An alternate response is to maintain food intake on a poor-quality diet and rather increase both the mean retention time and caecal volume. In this way digestibility is maintained (Yahav \& Choshniak, 1991). Naked mole-rats do not follow either of these patterns. Instead, they decrease food intake, food digestibility and caecal contents. Differences in 
energy content of the two diets (Table 1), however, enabled the maintenance of bodyweight. Constancy of body-weight, in turn, indicated that these animals were not adversely affected by the observed changes in gut function.

Changes in caecal size have been attributed to several causes and currently there are many different and often mutually exclusive theories explaining this phenomenon (Sakata, 1987; Wyatt et al. 1988). Sakata (1987) attributes increases in caecal size to increases in SCFA production, stimulating epithelial cell growth resulting in mucosal growth. Present findings do not concur with this suggestion. Instead caecal size diminishes with an increase in SCFA concentration and follows the same trends shown by Wyatt et al. (1988). Caecal enlargement is also attributed to increases in the non-digestible component of the diet, and therefore the bulk content within the caecum (Wyatt et al. 1988). The converse was true in the present study. Here the higher fibre content of the CAR diet did not result in an increased caecal volume; instead caecal volume declined significantly $\left(P=4.2 \times 10^{-4}\right)$. A decrease in caecal volume may be explained by decreased food intake (Wyatt et al. 1988), gut motility and microfaunal population (E1 Harith et al. 1976; El Harith \& Walker, 1977). Our findings concur with this theory, for both a marked decline in food intake and also a dramatic change in microfaunal population were observed (Table 2; Plate $1(a-e)$ ).

On the SP diet, the numbers of bacteria and ciliate protozoa were similar. The number of protozoa was unusually high in comparison with that previously reported (Clarke, $1977 \mathrm{a}$ ). This is attributed to the high content of starch and soluble sugars present in the fermentation substrate in the caecum (Orpin \& Letcher, 1978; Coleman, 1980). Whilst soluble sugars (including starch) are primarily digested and absorbed in the small intestine, some fractions of starch are resistant to $\alpha$-amylase and therefore enter the large intestine and caecum. These may then affect both fermentation and colonic function (Cummings \& Englyst, 1987). Given the high-starch content in SP (Table 1), it is highly likely that starch digestion was incomplete. Undigested starch enters the caecum, and provides an abundant energy substrate for microfauna. A large microfaunal population can, therefore, be supported. This manifests itself in a dramatic increase in microfaunal density and number which was most pronounced in protozoa.

These ciliates produce substantially less SCFA per unit volume than do bacteria. Change in microfaunal population with diet, most likely contributed to the observed differences in SCFA concentration on the two diets. Protozoa might inadvertently consume adherent starch-hydrolysing bacteria or they may deliberately prey upon bacteria (Clarke, 1977b). Increased protozoal numbers (on the SP diet) would thus reduce the number of bacteria in the population (Kurihara et al. 1968), and affect the fermentative ability (as reflected in SCFA concentration and gas production; Van Soest, 1982) of the caecum still further. A decline in starch concentration in the diet resulted in a dramatic decrease in the number of ciliate protozoa. Their absence might contribute to both the decrease in caecal DM mass and to the increase in the proportion of bacteria in the population.

Gas production per $\mathrm{g}$ DM was $2 \cdot 6$ times higher on the CAR diet than on SP, implying that the microfaunal population on the CAR diet better utilized their substrate. This could be attributed to several factors: (1) the amount of fibre for fermentation is higher, (2) the micro-organisms:substrate ratio is improved, (3) protozoa are less efficient in the degradation of fibre (Ryle \& Orskov, 1987), (4) a reduction in predatory protozoa results in an increase in the number of bacteria able to execute the fermentation process.

The constituents of gas production were also significantly different on the two diets (Table 4). On CAR, the gaseous mixture was mainly $\mathrm{CO}_{2}(91.2 \%)$ whereas on $\mathrm{SP}, \mathrm{CO}_{2}$ contribution halved $(45 \%)$ with $\mathrm{CH}_{4}(37 \%)$ and $\mathrm{H}_{2}(17 \%)$ accounting for a substantial portion of the gas mixture. The higher proportions of $\mathrm{CH}_{4}$ and $\mathrm{H}_{2}$ on the SP diet were attributed to the abundance of ciliate protozoa on this diet compared with that on CAR 
(Table 3). Ciliate protozoa produce $\mathrm{H}_{2}$ during fermentation (Wolin, 1979). Liberated $\mathrm{H}_{2}$ is promptly used by methanogenic bacteria. These are symbiotically attached to the cilia so as to readily avail themselves of the $\mathrm{H}_{2}$ as it is produced and combine both $\mathrm{CO}_{2}$ and $\mathrm{H}_{2}$ to form $\mathrm{CH}_{4}$ (Vogels et al. 1980). The decline in protozoa numbers on the CAR diet is therefore accompanied by a concomitant decrease in $\mathrm{CH}_{4}$ and $\mathrm{H}_{2}$ production. Bergen \& Yokoyama (1977) suggested that low rates of $\mathrm{CH}_{4}$ production are indicative of a more efficient fermentation process. If this is indeed true, the proportion of gases produced on the CAR diet confirm the greater efficiency of the fermentation process on a CAR diet when compared with that of SP. The fermentation stoichiometry on the CAR diet, however, does not appear to balance, for the proportion of gaseous $\mathrm{H}_{2}$ is considerably less than one would expect from the SCFA production rates. We are at a loss to explain this apparent incompatibility.

The total concentration of measured SCFA per g DM was $2 \cdot 6$ times greater on the CAR diet than on the SP diet (Fig. 2), thus compensating for the poorer quality of the CAR diet. In ruminants, the concentrations of SCFA are inversely proportional to food quality (Van Soest, 1982). This appears to hold true for these hind-gut fermentors, where SCFA production increased by the same order of magnitude as did fibre $(2 \cdot 5$-fold $)$.

The SCFA produced are an important source of energy to the host animal, in that they are absorbed into the blood and provide an energy-rich substrate for metabolism (Rechkemmer et al. 1988). The SCFA contributed $9.5 \%$ of the digestible energy intake on $\mathrm{SP}$ and this increased $2 \cdot 3$-fold to $22.1 \%$ of the digestible energy intake on CAR. The contribution of the SCFA to energy expenditure may be estimated using the following assumptions: (1) the volume of digesta remains relatively constant throughout the day (Herd \& Dawson, 1984): this assumption is thought to be valid given the absence of a circadian rhythm in these subterranean animals; (2) the energy released by the SCFA in the caecum is the same as that reported in the literature for each standard energy equivalent (Weast, 1979); (3) the energy expenditure of the animals is approximately $2 \cdot 3$ times the resting metabolic rate (Shoemaker et al. 1976). Using these assumptions, the contribution of SCFA to average daily energy expenditure (given that the resting metabolic rate at an ambient temperature of $30^{\circ}$ is $1.00 \mathrm{ml} \mathrm{O}_{2} / \mathrm{g}$ per h; Buffenstein \& Yahav, 1991) would be $5 \cdot 1 \%$ on SP and would increase 5 -fold $(25.5 \%)$ on the CAR diet. These estimates are not significantly different from those obtained by direct measurements from daily digestible energy intake. The contribution of SCFA to basal metabolic rate ranged between $11.6 \%$ on the SP diet, to $58.6 \%$ on the CAR diet. These values fall in the mid-range of those previously reported in this manner (Rechkemmer et al. 1988). Microbial fermentation on the higher-fibre diet, therefore, liberates a larger portion of the energy, trapped in fibre and otherwise unavailable to the host animal. The importance of this energy source to the host animal thus cannot be over-emphasized.

Micro-organisms present in the hind-gut of $H$. glaber, therefore, play an important role in its nutritional physiology. They enable the naked mole-rat to maximize the energetic returns of high-cost foraging in a subterranean arid-zone ecotope. Despite changes in fibre content of the food, digestibility is maintained at exceptionally high levels $(90-95 \%)$. A change in diet quality from 65 to $157 \mathrm{~g} \mathrm{NDF} / \mathrm{kg} \mathrm{DM}$ and from 638 to $258 \mathrm{~g}$ starch $/ \mathrm{kg} \mathrm{DM}$ resulted in a marked increase in bacterial density and a decrease in that of ciliate protozoa. This alteration in microbial population and density improved the efficacy of fermentation. Whilst SCFA concentration and rate of gas production per g DM increased significantly on the CAR diet, DM within the caecum declined markedly. These combined effects of greater efficiency per unit mass and a decline in mass meant that diet type did not affect the overall rate of SCFA and gas production per $40 \mathrm{~g}$ animal. Despite the fact that mole-rats consumed less food when given a diet $2 \cdot 5$ times higher in fibre (than that consumed on SP), 
these animals derived similar amounts of energy from their diet and maintained body mass. The advantages of this for a subterranean mammal randomly foraging by digging through compacted soil in the arid regions of North East Africa are, therefore, obvious.

The authors wish to thank Professor Jenny Jarvis for providing the animals used in this study. The foods used in this study were kindly analysed by Ms Joan Bernan of the Nutrition Laboratory at the Animal and Dairy Science Research Institute. Mr Jock Davies and $\mathrm{Mr}$ Brian Kurnick are gratefully thanked for enabling us to use the equipment for gas and SCFA analyses at the Animal and Dairy Research Institute, at Irene, Transvaal. This work was supported by a CSIR/FRD grant and approved by the Animal Ethics Committee (No. 89/34/2) at the University of the Witwatersrand.

\section{REFERENCES}

Bergen, W. E. \& Yokoyama, M. T. (1977). Productive limits to rumen fermentation. Journal of Animal Science 46, $573-584$.

Buffenstein, R. \& Yahav, S. (1991). Is the naked mole-rat Heterocephalus glaber an endothermic yet poikilothermic mammal? Physiological Zoology (In the Press).

Carol, E. J. \& Hungate, R. E. (1954). The magnitude of microbial fermentation in bovine rumen. Applied Microbiology 2, 205-214.

Clarke, R. T. J. (1977 a). Gut micro-organisms. In Microbial Ecology of the Gut, pp. 36-71 [R. T. J. Clarke and T. Bauchop, editors]. New York and London: Academic Press.

Clarke, R. T. J. $(1977 \mathrm{~b})$. Protozoa in the rumen ecosystem. In Microbial Ecology of the Gut, pp. 251-275 [R. T. J. Clarke and T. Bauchop, editors]. New York and London: Academic Press.

Colcman, G. S. (1980). Rumen ciliate protozoa. Advances in Parasitology 18, 12I-173.

Cummings, J. H. \& Englyst, H. N. (1987). Fermentation in the human large intestine and the available substrates. American Journal of Clinical Nutrition 45, 1243-1255.

El Harith, E. A., Dickerson, J. W. T. \& Walker, R. (1976). Potato starch and caecal hypertrophy in the rat. Food and Cosmetic Toxicology 14, 115-121.

El Harith, E. A. \& Walker, R. (1977). Some factors influencing caecal enlargement induced by raw potato starch in the rat. Food Chemistry 2, 279-289.

Gross, J. E., Wang, Z. \& Wunder, B. A. (1985). Effects of food quality and energy needs: changes in gut morphology and capacity of Microtus ochrogaster. Journal of Mammalogy 66, 661-667.

Herd, R. M. \& Dawson, T. J. (1984). Fibre digestion in the emu, Dromains novaehollandiae, a large bird with a simple gut and high rates of passage. Physiological Zoology 57, 70-84.

Hoover, W. H. \& Heitmann, R. N. (1972). Effect of dietary fibre levels on weight gain, caecal volume and volatile fatty acid production in rabbits. Journal of Nutrition $102,375-380$.

Janis, C. (1976). The evolutionary strategy of the Equidae and the origins of rumen and caecal digestion. Evolution 30, 757-774.

Jarvis, J. U. M. \& Bennett, N. C. (1990). Ecology and behaviour of the family Bathyergidae. In Biology of the Naked Mole-rat, pp. 66-96 [P. W. Sherman, J. U. M. Jarvis and R. D. Alexander, editors]. Princeton: Princeton University Press.

Kingdom, J. (1974). East African Mammals, vol. 11, part B, pp. 489-494. New York and London: Academic Press.

Kurihara, Y., Eadie, J. M., Hobson, P. N. \& Mann, S. O. (1968). Relationship between bacteria and ciliate protozoa in the sheep rumen. Journal of General Microbiology 51, 267-288.

Lovegrove, B. G. (1989). The cost of burrowing by the social mole-rats (Bathyergidae) Cryptomys damarensis and Heterocephalus glaher: the role of soil moisture. Physiological Zoology 62, 449-469.

McBee, R. H. (1970). Metabolic contributions of the caecal flora. American Journal of Clinical Nutrition 23, $1514-1518$.

McBee, R. H. (1977). Fermentation in the hindgut. In Microbial Ecology of the Gut, pp. 185-222 [R. T. J. Clarke and T. Bauchop, editors]. New York and London: Academic Press.

Orpin, C. G. \& Letcher, A. J. (1978). Some factors controlling the attachment of the rumen holotrich protozoa Isotricha intestinalis and I. prostoma to plant particles in vitro. Journal of General Microbiology 106, 33-40.

Parra, R. (1978). Comparison of foregut and hindgut fermentation in herbivores. In The Ecology of Arboreal Folivores, pp. 205-229 [G. G. Montgomery, editor]. Washington, DC: Smithsonian Institute Press.

Porter, A. (1957). Entozoa and endophyta of the naked mole-rat. Proceedings of the Zoological Society, London $128,515-527$.

Rechkemmer, G., Ronnau, K. \& Engelhardt, W. V. (1988). Fermentation of polysaccharides and absorption of short chain fatty acids in the mammalian hindgut. Comparative Biochemistry and Physiology 90A, 563-568. 

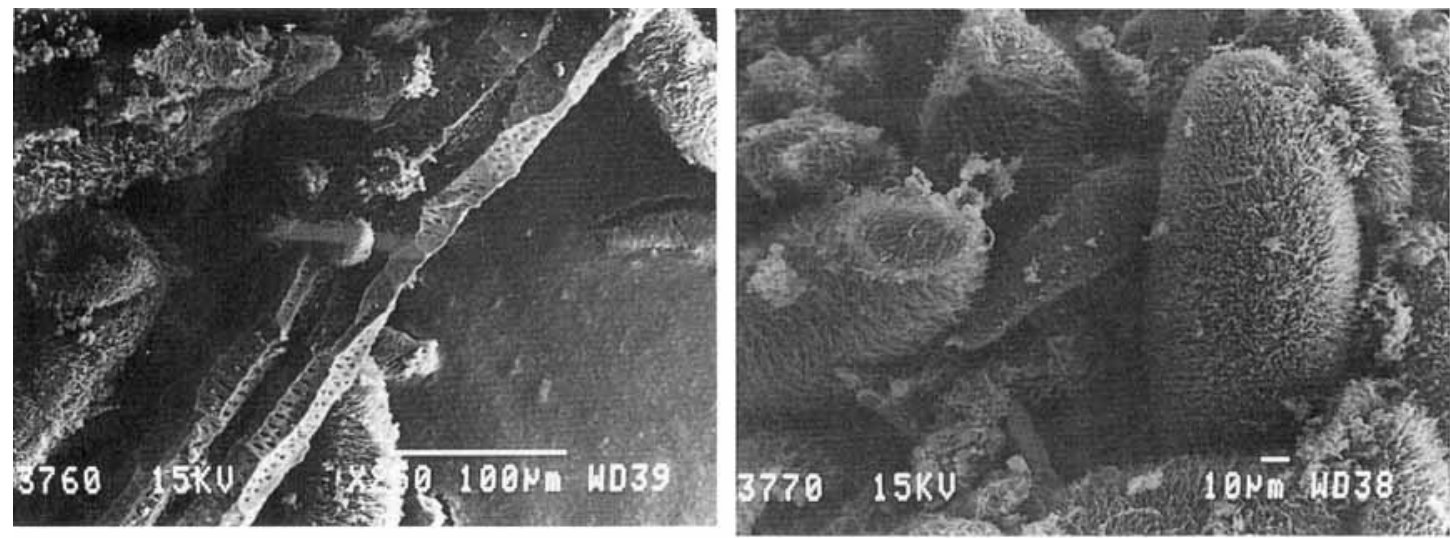

a

$$
\text { b }
$$

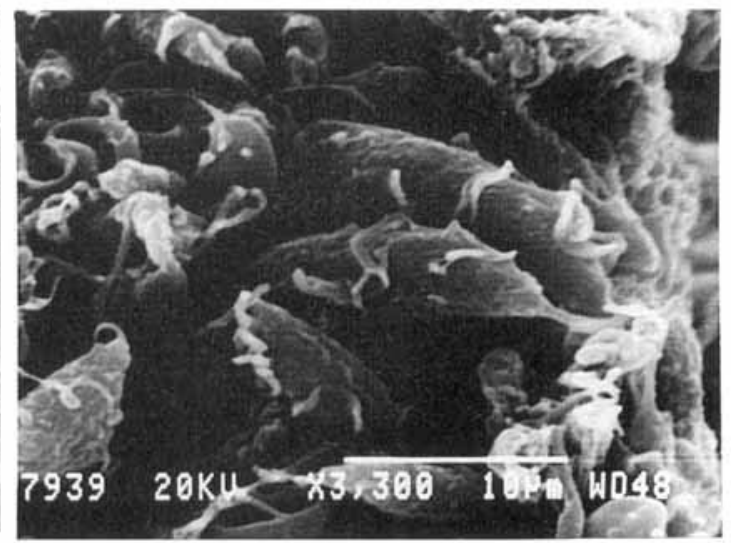

$3761515 \mathrm{KV}$ $10 N \bar{m}$ HDE

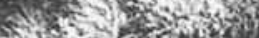
stapes 36

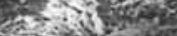
\&. siviste xistonges c

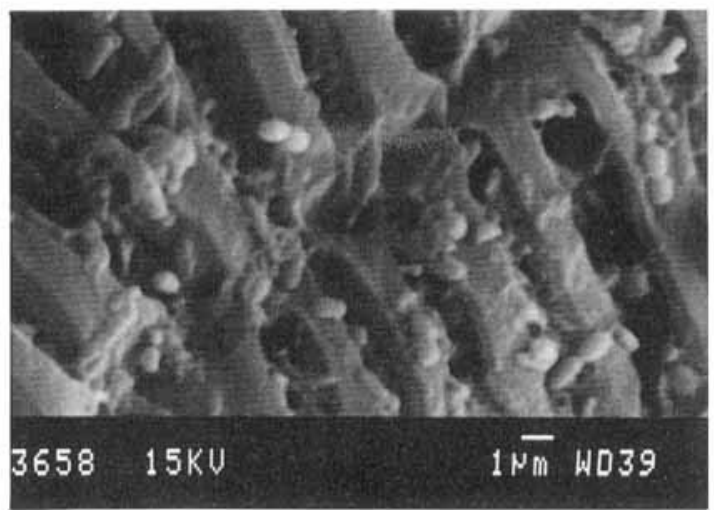

e 
Ryle, M. \& Ørskov, E. R. (1987). Rumen ciliates and tropical feeds. World Animal Review 64, 21-30.

Sakata, T. (1987). Stimulatory effect of short chain fatty acids on epithelial cell proliferation in the rat intestine: a possible explanation for trophic effects of fermentable fibre, gut microbes and luminal trophic factors. British Journal of Nutrition 58, 95-103.

Shoemaker, V. E., Nagy, K. A. \& Costa W. R. (1976). Energy utilization and temperature regulation by jackrabbits (Lepus californicus) in the Mojave desert. Physiological Zoology 49, 364-375.

Sibly, R. M. (1981). Strategies in digestion and defecation. In Physiological Ecology, an Evolutionary Approach to Resource Use, pp. 109-139 [C. R. Townsend and P. Calow, editors]. Sunderland, Massachusetts: Sinauer Associates.

Van Soest, P. J. (1982). Gasterointestinal fermentation. In Nutritional Ecology of the Ruminant, pp. 152-229 [P. J. Van Soest, editor]. Corvallis, Oregon: O. and B, Books.

Vogels, G. D., Hoppe, W. F.\& Stumm, C. K. (1980). Association of methanogenic bacteria with rumen ciliates. Applied and Environmental Microbiology 40, 608-612.

Weast, R. C. (1979). Handbook of Chemistry and Physics, 60th ed. Boca Raton: CRC Press Inc.

Wolin, M. J. (1979). The rumen fermentation: a model of microbial interactions in anaerobic ecosystem. In Advances in Microbial Ecology, pp. 49-77 [M. Alexander, editor]. New York: Plenum Publication Corporation.

Wyatt, G. M., Horn, N., Gee, J. M. \& Johnson, I. T. (1988). Intestinal microflora and gastrointestinal adaptation in the rat in response to non-digestible dietary polysaccharides. British Journal of Nutrition 60, $197-207$.

Yahav, S. \& Buffenstein, R. (1991). The effect of temperature on caecal fermentation processes in an ectothermic mammal, Heterocephalus glaber. Joumal of Comparative Physiology (In the Press).

Yahav, S. \& Choshniak, I. (1990). Response of the digestive tract to low quality dry food in the fat jird (Meriones crassus) and in the levant vole (Microtus guentheri). Journal of Arid Environments 19, 209-215.

Zar, J. H. (1984). Biostatistical Analysis. New Jersey: Prentice Hall.

\section{EXPLANATION OF PLATE}

Plate 1. Scanning electron microscope photographs of $(a)$ caecal contents when the animals were fed on sweet potato (SP), $(b)$ and $(c)$ different species of holotrich protozoa present in the caecum of animals fed on SP, $(d)$ caecal protozoa found in animals fed on carrots (CAR), (e) bacteria attached to CAR fibres. For details of diet see Table 1 and p. 250. 